\title{
US-Tyres: Upholding a WTO Accession Contract - Imposing Pain for Little Gain
}

\author{
STEVE CHARNOVITZ* \\ George Washington University Law School \\ BERNARD HOEKMAN * * \\ World Bank and CEPR
}

\begin{abstract}
In 2009, the United States imposed additional tariffs for a three-year period on imports of automotive tires from China under a special-safeguard provision included in China's Protocol of Accession to the WTO. China challenged the measure in the WTO. The case marked the first WTO dispute in which a challenged safeguard was upheld by the Appellate Body; the first in which an accession protocol was used successfully as a defense; and the first that China lost as a complaining party. It also was noteworthy in that the safeguard was sought by a labor union, not the domestic industry. This paper reviews the WTO Appellate Body's findings and discusses a number of the legal and policy implications regarding China's Accession Protocol, the Safeguards Agreement, and WTO accession law, as well as economic aspects of the case.
\end{abstract}

\section{Introduction}

In US-Tyres, the World Trade Organization (WTO) Appellate Body upheld in full the Panel Report which had affirmed a three-year special-safeguard action that the United States imposed in 2009 on certain tire imports from China. The safeguard was a centerpiece of the Obama Administration's early trade policy ${ }^{1}$ and proved controversial due to its unusual initiation and its counterproductive economic effects (Eisenstein, 2010-2011; Ikensen, 2009). The legacy of US-Tyres includes several distinctions: It marked the first WTO dispute in which a challenged

\footnotetext{
* Email: scharnovitz@law.gwu.edu.

**Email: bhoekman@worldbank.org.

This paper was prepared for The American Law Institute project Legal and Economic Principles of World Trade Law and reviews the WTO Appellate Body Report United States-Measures Affecting Imports of Certain Passenger Vehicle and Light Truck Tyres from China, WT/DS399/AB/R, 5 September 2011, adopted 5 October 2011, in conjunction with the Panel Report. The views expressed are those of the authors only. We thank Simon Schropp for helpful comments on an earlier draft as well as participants at the workshop at the European University Institute for their suggestions.

1 In his State of the Union Address on 24 January 2012, President Obama declared, 'We brought trade cases against China at nearly twice the rate as the last administration - and it's made a difference. Over a thousand Americans are working today because we stopped a surge in Chinese tires' (Obama, 2012).
} 
safeguard was upheld (the only previous General Agreement on Tariffs and Trade (GATT) or WTO ruling upholding a challenged safeguard was in 1951); it is the first dispute in which an accession protocol was used successfully as a defense; and it is the first case that China lost as a complaining party.

The special safeguard was part of the contract that enabled China to join the WTO. The Protocol of Accession negotiated between WTO Members and China provides for a Transitional Product-Specific Safeguard Mechanism (TPSSM). This Mechanism (WTO, 2001: para. 16) specifies that in cases where increased imports from China cause or threaten to cause market disruption for domestic producers of like or directly competitive products, WTO Members may request consultations with China 'with a view to seeking a mutually satisfactory solution, including taking measures under the WTO Agreement on Safeguards' (see Appendix for an excerpt from the TPSSM). If China agrees that its exports are causing such market disruption, it may take remedial action (presumably a voluntary export restraint see Lee, 2002). If consultations do not resolve the matter within 60 days, the importing country may 'withdraw concessions or otherwise limit imports to the extent necessary to prevent or remedy' such market disruption. For market disruption to exist, imports need to 'be increasing rapidly, either absolutely or relatively, so as to be a significant cause of material injury, or threat of material injury to the domestic industry' based on 'objective factors, including the volume of imports, the effect of imports on prices for like or directly competitive articles, and the effect of such imports on the domestic industry'. Measures may be imposed only for such period of time as needed to prevent or remedy market disruption. Prior to imposing such a measure, the importing Member must collect evidence from interested parties and provide a written notice of the decision, including the reasons for imposing a measure. Under the Protocol, a remedy under the TPSSM can only be imposed during the first 12 years following China's accession, i.e., until mid-December 2013.

The negotiation of a transitional safeguard mechanism as part of China's accession protocol appeared to reflect a desire by WTO members to make it easier to take action against China if imports from China following its accession were to rise too fast. ${ }^{2}$ The legal standard for import relief under the Accession Protocol is both less stringent (i.e., easier to satisfy) and less clearly defined than the criteria that must be satisfied in order to comply with the rules of the general WTO safeguard mechanism. Moreover, under the WTO Agreement on Safeguards, all exporters of the product concerned are ostensibly affected because safeguard measures are supposed to be applied on an MFN basis. TPSSMs are similar to antidumping or countervailing-duty actions in that they target specific countries, but are subject to fewer detailed procedural requirements and entail no presumption about 'unfair' behaviour by foreign firms or government.

2 For a good analysis of the history of the TPSSM, see Spadi (2002). 
By mid-2010, only two WTO Members besides the United States had imposed a TPSSM safeguard: Turkey and India (Ji and Huang, 2011: 11). Several countries had launched such investigations, but they did not eventuate in a safeguard. Before 2009, the same situation had occurred in the United States. Although six petitions for import relief under the relevant US statute (Section 421 of the Trade Act of 1974, as amended) were filed by US industries between 2001 and 2008, four of which resulted in findings of market disruption and material injury by the investigating authority, i.e., the US International Trade Commission (USITC), President George W. Bush decided in all four cases that imposition of trade barriers was not in the national interest.

This changed in 2009 with the imposition of US tariffs on imports of certain passenger and light truck tires from China (Grimmett, 2011). Not only was this the first instance in which the United States took action under the TPSSM, it was also the first instance of a 'China safeguard' being contested by China in the WTO. It thus raised questions that have not yet been dealt with in WTO dispute settlement including the interpretation of the TPSSM and the relationship between 'special safeguard' measures and the global safeguard mechanism that is provided for under the WTO Agreement.

US-Tyres is also of interest because it illustrates the tension between the national 'producer-centric' nature of WTO rules and obligations and the ongoing process of globalization - the geographic fragmentation and 'vertical specialization' of production. The latter reduces the net benefits of trade-policy instruments to multinational companies, which have incentives to undertake production activities in low(er)-cost countries. This process of specialization has implications for workers who are negatively affected by decisions to move production to other countries. A basic policy question raised by the case is whether and how trade policy should be used to address the adjustment costs associated with globalization.

The paper proceeds in five sections: Section 1 introduces the dispute and provides the economic backdrop. Section 2 provides a summary of the four legal decisions in the dispute, the USITC, the WTO Panel, the Appellate Body, and the WTO Dispute Settlement Body (DSB). Section 3 discusses the implications of the Tyres decision for WTO jurisprudence. Section 4 offers some economic and policy-related observations. Section 5 concludes.

\section{Economic background of the case}

The Tyres case was brought by the United Steel, Paper and Forestry, Rubber, Manufacturing, Energy, Allied Industrial and Service Workers International Union (USW). The USW argued that imports of Chinese tires - worth some $\$ 2$ billion in 2008 (about $25 \%$ of total imports) - had caused market disruption and materially injured the domestic industry. Upon investigation, the USITC agreed with the USW and recommended the imposition of additional tariffs for a three-year period (at a rate of $55 \%$ for the first year, $45 \%$ for the second, and $35 \%$ in the third). The USITC also suggested that the President 'take such action as is within his 
authority to direct the US Department of Commerce and the US Department of Labor to expedite the consideration of petitions for trade adjustment assistance filed by domestic firms or workers producing tires' (USITC, 2009: 30). ${ }^{3}$ The President authorized the imposition of tariffs, although at lower rates than recommended $(35 \%, 30 \%$, and $25 \%$ for years 1,2 , and 3 , respectively). These tariffs expired near the end of September 2012.

This case was unusual in being brought by a union (representing workers) rather than by the domestic industry (firms). Indeed, it was even more unusual in that the US industry did not support the case and in some instances opposed the imposition of trade measures. The USW argued that the major increase in imports of tires from China between 2004 and 2008 had contributed to the loss of 4,000 US tire-related jobs and that announced plant closings implied another 3,000 jobs would be lost in 2009 (USITC, 2009: 14). The quantity of imports from China more than tripled during the 2004-2008 period, rising from 14.6 million tires in 2004 to 46.0 million tires in 2008. Imports from other sources fell from 98 to 93 million units during this period. US production of tires fell from 218 to 160 million units between 2004 and 2008. Thus, the ratio of Chinese imports to domestic production rose from $6.7 \%$ to $28.7 \%$ of US output; imports from other sources grew from $45 \%$ to $58 \%$.

While not denying these trends in domestic employment and production, and in imports, the tire industry argued that the tires produced in China were low-cost, relatively low-quality products that could not be economically produced in the US. These so-called 'tier-3' tires constituted only a small share of total output of domestically produced tires. Most production of tires in the US centers on higherquality branded products (tier 1 and tier 2), which were much less affected by import competition from China or other countries. According to the USITC (2009), only $18.6 \%$ of US production involved tier-3 tires. Given the quality differentiation/market segmentation of passenger and light-truck tires, the industry argued that higher trade barriers would raise the prices of the affected low-cost tires without doing much if anything to increase US employment as the relevant production had largely disappeared (Tire Industry Association, 2009). ${ }^{4}$ China

3 Trade Adjustment Assistance is available to workers negatively affected by import competition as well as those who have been affected by outsourcing. As discussed below, the latter situation is more relevant to the case at hand. Along with agreeing to a safeguard, President Obama called for an expedited petitioning process.

4 In a 2009 press release, the Association stated its belief that the action was 'a politically motivated decision that will end up costing more jobs than it saves. These tariffs will not bring back the jobs that the union claims have been lost; it will not create any new tire manufacturing jobs, and it will most likely result in the loss of thousands of retail tire industry jobs in the U.S., affecting everyone from the shop that services your tire to the tire wholesalers - many of whom are small businesspeople struggling to stay afloat in this economy ... The tire manufacturers made the decision years ago to shift production of lower-cost tires out of the U.S. All this action will do is force the tire manufacturers to shift production of these lower-cost tires to other countries, such as Brazil and India. The bottom line is that despite what the union and the President believes, these jobs are not coming back ... This tariff will price tires out of reach of many consumers, and will lead to a tightening in the remaining supply of lower-cost tires. Also, given that the lower-cost tires 
Table 1. US tire imports (value, 2007-2011, US\$ million and percent)

\begin{tabular}{lrrrrrrrr}
\hline \hline Country & 2008 & 2009 & 2010 & 2011 & $2008-09$ & $2009-10$ & $2010-11$ & $2008-11$ \\
\hline Canada & 1,444 & 1,483 & 1,783 & 1,942 & $2.7 \%$ & $20.2 \%$ & $8.9 \%$ & $34.5 \%$ \\
China & 1,970 & 1,742 & 1,525 & 1,801 & $-11.6 \%$ & $-12.4 \%$ & $18.0 \%$ & $-8.6 \%$ \\
Japan & 1,160 & 1,078 & 1,495 & 1,469 & $-7.2 \%$ & $38.7 \%$ & $-1.8 \%$ & $26.5 \%$ \\
Korea & 786 & 639 & 1,171 & 1,453 & $-18.6 \%$ & $83.1 \%$ & $24.1 \%$ & $85.0 \%$ \\
Thailand & 332 & 296 & 536 & 803 & $-10.8 \%$ & $80.8 \%$ & $49.8 \%$ & $141.7 \%$ \\
Mexico & 298 & 275 & 390 & 569 & $-7.9 \%$ & $41.9 \%$ & $45.9 \%$ & $90.8 \%$ \\
Indonesia & 175 & 186 & 330 & 455 & $6.5 \%$ & $77.3 \%$ & $37.7 \%$ & $160.2 \%$ \\
Germany & 243 & 180 & 229 & 350 & $-26.0 \%$ & $27.4 \%$ & $52.8 \%$ & $44.1 \%$ \\
Brazil & 298 & 249 & 331 & 340 & $-16.5 \%$ & $33.0 \%$ & $2.8 \%$ & $14.2 \%$ \\
Taiwan & 128 & 80 & 188 & 217 & $-37.4 \%$ & $134.0 \%$ & $15.4 \%$ & $69.1 \%$ \\
World & 7,934 & 6,890 & 8,865 & 10,657 & $-13.2 \%$ & $28.7 \%$ & $20.2 \%$ & $34.3 \%$ \\
& & & & & & & \\
\hline \hline
\end{tabular}

Source: USITC website.

argued these points in the WTO dispute, asserting that the US industry had voluntarily engaged in outsourcing of low-end tires and that 'the reduction in domestic manufacturing of tires and the increase in imports from China were the consequences of deliberate economic decision-making by the US tyre industry' (WTO, 2010: para 7.9).

The US tire industry has experienced major restructuring and change in the last 30 years. It dominated the world market in the early 1970s, accounting for some $60 \%$ of global production. Four of the top five producers were US companies (Rajan et al., 1997). By 1991, the US share of global output had fallen to $17 \%$ and has remained near that level since; in 2010 it was about $15 \%$. There is only one large US-owned producer in the industry (Goodyear), and only one relatively small company (Cooper) that focuses primarily on tier-3 tires. The lion's share of the global market is taken by foreign-owned firms, with Michelin and Bridgestone accounting for about 35\% of the total (Bank of America/Merrill Lynch, 2010). Seven of the ten firms that produce tires in the United States had affiliates or joint ventures in China in 2008 (Bridgestone, Cooper, Goodyear, Michelin, Pirelli, Toyo, and Yokohama) (USITC, 2009: 49).

Although China's exports of tires to the United States grew rapidly in the 2000s, imports from other sources dominate-accounting for some $75 \%$ of all imports in 2008 (Table 1). A key feature of the case was that imports from China were concentrated in a specific segment of the market - the unbranded, low-end. This presumably was a major factor motivating the launch by the USW of a Section 421

imported from China help those most vulnerable in this current economy - working-class citizens - we are deeply concerned that many consumers may delay or even defer replacing their tires when necessary, thus creating a potential safety hazard on America's roads.' See Tire Industry Association (2009). A number of these arguments appear to be based on Prusa (2009). 
safeguard petition which by definition involves a sole focus on China, ignoring other sources of import competition. However, as pointed out by Prusa (2009) and the industry representatives during the USITC investigation, the effectiveness of a safeguard in preserving US production is degraded by the ease with which other foreign suppliers can enter the market at prices close to those charged by Chinese firms. The evidence suggests that such substitution has occurred and that other suppliers have offset the decline in Chinese exports that was induced by the imposition of tariffs.

\section{Summary of the national and international safeguard rulings}

\subsection{USITC decision}

The competent US domestic authority (i.e., the USITC) split on whether the special safeguard was warranted. All commissioners agreed that subject imports from China were 'increasing rapidly' and that these imports were causing 'material injury' to the domestic competing industry. In doing so, the Commission noted that 'material injury' was a lesser degree of injury than 'serious injury' which is the requirement for a normal safeguard (i.e., Section 201). But there was divergence on the issue of causation. The four-commissioner majority found that imports were a 'significant cause' of material injury, and noted that Section 421 (unlike Section 201) did not require a weighing of causes. The dissenters disagreed that there was sufficient causal nexus between the imports and the injury. Rather, the two dissenters explained that the decline in domestic production was the result of the economic recession and a strategic decision by US producers to shift certain production to China as well as other countries. The dissent also noted that some parts of the domestic industry did not support the petition for relief. As is its usual practice, the Commission focused only on Section 421, not the international-law requirement, in this case the Accession Protocol.

In calling for a three-year safeguard, the USITC predicted that it 'would significantly improve the competitive position of the domestic industry' and that non-Chinese imports 'will capture a minority of the reduction in subject imports' (USITC, 2009: 35-37). The USITC also estimated that the safeguard would add 'nearly 1,200 jobs on a full time basis' and that the effect on US welfare would range from a $\$ 71$ million loss to a $\$ 73.3$ million gain (USITC, 2009: 37-38).

\subsection{Panel decision}

Like Section 201 of the Trade Act of 1974 (global safeguards), Section 421 does not provide for judicial review in the United States. Thus, the only way to appeal a safeguard action is by bringing a case to the WTO. The Panel unanimously upheld the US safeguard, which was challenged by China as a violation of Paragraph 16 of the China Protocol. When it needed to apply the various vague terms in the TPSSM, the Panel drew heavily on past WTO safeguard jurisprudence and other 
case law to fill in gaps in the interpretation of the provisions of the TPSSM. Nevertheless, the Panel avoided importing it all and, in contrast to previous global safeguard disputes, did not go out of its way to find a violation.

Drawing from WTO jurisprudence, the Panel explained that its standard of review was to make an 'objective assessment' of the matter before it and to consider whether the USITC evaluated the 'objective factors' in Paragraph 16 and whether the Commission provided a 'reasoned and adequate explanation of its determination' (WTO, 2010: paras. 7.11, 7.15). Using dictionaries to parse the meanings of the key terms in Paragraph 16, the Panel concluded that USITC did not fail to evaluate properly whether imports from China were increasing rapidly. On causation, the Panel found that Section 421 did not violate the Protocol, as such, nor did it violate it as applied. Drawing from dictionaries, the Panel concluded that a 'significant' cause required more than a mere contribution, but did not require a cause more significant than other causative factors (WTO, 2010: para. 7.158). After reviewing the record, the Panel found that the evidence was sufficient to support the Commission's affirmative finding of causation.

Borrowing from WTO case law on subsidies, the Panel imputed a nonattribution test to the definition of causation (though not a full-blown analysis), ${ }^{5}$ but disagreed with China that the USITC had attributed to imports the injury caused by other factors. Although the Panel found fault with the Commission's assessment of one plant closing (WTO, 2010: para. 7.299), the Panel stated that there was not convincing evidence that US producers 'voluntarily' closed US production capacity independent of competition from China, and therefore the Panel upheld the Commission. While noting that the dissenting Commissioners concluded that the outsourcing of production was independent of imports, the Panel held that it would be inappropriate for the Panel simply to make a choice between the views of the majority and the dissenting commissioners' (WTO, 2010: para. 7.321). Another 'other' factor considered by the Panel was non-Chinese imports which were over two-thirds of total imports during the entire period of investigation. Nevertheless, the Panel found that 'the dominant feature of the US market was the rise of subject imports from China at the expense of both nonsubject imports and the US industry' (WTO, 2010: para. 7.367).

China also challenged the US safeguard as a violation of GATT Articles I:1 and II:1.6 The GATT Article I claim was warranted because the US safeguard imposed additional duties solely on tires from China. The Panel's resolution of this claim is deeply mysterious:

7.418. China's GATT 1994 claims are entirely dependent on its claims under Paragraph 16 of the Protocol. ${ }^{557}$ Since we have not accepted China's claims under

5 WTO (2010, para. 7.394).

6 Notably, China did not lodge a GATT Article XIX claim or argue that its 'unforeseen developments' requirement was incorporated into the Protocol. 
Paragraph 16 of the Protocol, we similarly do not accept China's claims under Article I:1 and II:1 of the GATT 1994.

557 The dependent nature of China's GATT 1994 claims is shown by China's argument that there is 'also' a GATT 1994 violation because of the additional duties 'not having been justified as emergency action under relevant WTO rules' (See China's First Written Submission, paras. 417 and 421).

What does the Panel mean? The parallelism between not accepting China's Protocol claims and its GATT claims suggests that the Panel resolved them both in the same way; namely, by ruling against them. Although the GATT claim was not appealed, support for this explanation can be found in the Appellate Body Report, which stated that the Panel 'rejected consequential claims by China that the United States acted inconsistently' with GATT Articles I and II (WTO, 2011a: para. 6). Moreover, in its Report, the Panel concluded that 'the United States did not fail to comply with its obligations under Paragraph 16 of the Protocol and Articles I:1 and II:1 of the GATT 1994' (WTO, 2010: para. 8.1). So there is considerable support for the thesis that the Panel ruled that the US safeguard was not a violation of GATT Articles I and II. On the other hand, since the US safeguard was not carried out in accordance with the MFN principle, a finding that there was no Article I violation was hardly obvious, and yet here the Panel offered no explanation for why there was no violation.

The rather contorted explanation of the Panel quoted above might be read to suggest that China had predicated its GATT claims on being vindicated on its Protocol claims. Such a condition precedent would be an odd posture for a WTO complainant who would typically want to win the second claim even if it did not win the first claim. Yet perhaps that was China's intention, to claim a GATT violation only if the United States could not raise the Protocol as a defense. But if that were the case, the right outcome would have been to refrain from issuing a ruling on the GATT claim rather than to rule against it.

Unfortunately, there is no way to know exactly what China's GATT claim was. The Panel asserts that the claim was 'dependent' but offers no evidence other than directing the reader to 'see' China's First Written Submission, which the Panel fails to append to its Report. This Submission is not posted on the WTO website, and the WTO Secretariat has confirmed that it is being kept confidential. Based on the Panel's brief characterization of China's claim, it seems that China argued that there was a violation of GATT Articles I and II because the safeguard could not be justified as an emergency measure under GATT Article XIX. ${ }^{7}$ If that is what China meant, then it was wrong for the Panel to mischaracterize the GATT claim as being dependent on the Protocol claim. All in all, it is hard to escape the conclusion that the Panel was intentionally nontransparent in addressing the Article I claim.

7 China's Request for Consultations, WT/DS399/1, 16 September 2009, appears quite clear that China was asserting the GATT claims separately from its claims under the Accession Protocol. 


\subsection{Appellate body decision}

China appealed the Panel's holding on the issues of increased imports, causation, and on whether the Panel made an objective assessment of the facts. Surprisingly, China did not appeal the Panel's puzzling holding on GATT Article I. Although critical of the Panel on a few specific points, ${ }^{8}$ the Appellate Body upheld the Panel's ruling in its entirety on the interpretation and application of the TPSSM. After using a dictionary to parse the meaning of imports 'increasing rapidly', the Appellate Body upheld the Panel on its application of the increasing imports criterion. On the causation test, the Appellate Body parsed the term 'significant cause' in China Protocol Paragraph 16.4 and held that this 'significant cause' requirement is not a more rigorous standard than found in other WTO agreements which require that imports 'cause' injury. Instead, the Appellate Body postulated that the 'object and purpose of the Protocol' leads to an interpretation wherein temporary relief will be available whenever rapidly increasing imports are making an important contribution to material injury of the domestic industry (WTO, 2011a: paras. 181, 184). On the application of the TPSSM causation standard, the Appellate Body found that the TPSSM 'gives investigating authorities a certain degree of discretion in selecting the methodology to assess the existence of a causal link' (WTO, 2011a: para. 190), and therefore the Appellate Body did not agree with China that the TPSSM required the USITC to find a correlation between the year-by-year changes in imports and injury factors. China also appealed on the grounds that competition between its tires and US domestic production was 'highly attenuated' with US production being concentrated in tier-1 tires and China's exports in tiers 2 and 3. In response, the Appellate Body noted that the USITC properly established the presence of both domestic and Chinese tires in tiers 2 and 3 and significant competition between them.

The Appellate Body also agreed with the Panel that the need for nonattribution analysis was 'inherent' in the TPSSM (WTO, 2011a: para. 252). The Appellate Body examined each of the other causes put forward by China, and concluded that none of them negated the Panel's finding that imports were an important cause of injury. Regarding the domestic industry's business strategy, China objected to the Panel's upholding of the USITC conclusion that the closing of the Bridgestone tire plant could be attributed to subject imports. In response, the Appellate Body refused to consider this appeal on the grounds that it was improperly pleaded (WTO, 2011a: para. 273). It is interesting to note that the debate about Bridgestone at the USITC and the WTO was not based on the evaluation of market data but rather on the interpretation of a press release and news article at the time of the plant closing. China also objected to the Panel's refusal to choose between the conclusion of the Commission's majority and dissent regarding the so-called 
independent business strategy. Here the Appellate Body agreed with the Panel that it was not its role to decide whether the majority or the dissent was actually correct.

China also appealed on the grounds that the Panel sought to buttress the evidence for causation by relying on information not in the USITC determination. The Appellate Body explained that a Panel is not precluded from relying upon evidence in the USITC staff report even though such evidence was not marshaled by the investigating authority in its decision. In addition, the Appellate Body rejected this appeal by China due to a pleading error (WTO, 2011a: paras. 330-331).

\subsection{DSB adoption}

One month after the Appellate Body handed down its Report (which came 99 days after the appeal), the DSB adopted the US-Tyres Panel and Appellate Body Reports. China complained that the Appellate Body had rendered the term 'significant' futile (probably meaning inutile) and that by upholding the safeguard, the WTO would be sending the 'wrong signal' about 'protectionist measures' (WTO, 2011b, para. 9). Several other WTO Member governments also spoke out, but mainly to express concern that the Appellate Body had missed the 60- and 90-day deadlines in the WTO Dispute Settlement Understanding (DSU) without sufficient consultation of the parties.

\section{Implications of the decision for WTO case law}

The US-Tyres case demonstrates the use of an accession agreement to justify a protectionist measure that would not have been possible under multilateral WTO law. Although enabling protectionism is not the central purpose of WTO law, protection is certainly one purpose, and in this episode the WTO performed as the WTO community expected that it would. Had WTO judges ruled against the safeguard, such an outcome would have been unexpected (given the facts supporting the USITC ruling), and would have led to criticism of the WTO and perhaps made it more difficult to consummate ongoing accession agreements, such as the negotiations with Russia.

What follows examines the implications of the case for the China Protocol, for WTO Safeguards law, and for WTO Accession law.

\subsection{Interpretation of the TPSSM}

The most positive thing one can say about the Appellate Body decision is that it upheld the contract wherein China paid a higher price than any other country to join the WTO. The price China paid was to agree to a myriad of unique rules that only apply to the China WTO membership. US-Tyres will be the leading precedent if there are any future TPSSM cases, but because this special safeguard expires before the end of 2013, it is possible that no additional disputes will arise.

WTO accession agreements are a unique feature of international law because they can require the applicant government to agree to applicant WTO-Plus 
obligations, whereby the applicant signs on to higher obligations than incumbents, and to incumbent WTO-Minus provisions, whereby the applicant agrees that incumbents will have a diminished level of obligations toward them (see Charnovitz, 2008: 871). The TPSSM is an example of an incumbent WTO-Minus provision that allows the United States to impose a safeguard against China without complying with the usual rules in the WTO Agreement on Safeguards. Note also that the TPSSM is not reciprocal; China cannot impose such measures on the United States.

The TPSSM provided tangible benefits to the United States because, without it, a safeguard might not have been possible. As the USITC noted, lower-price imports from countries other than China were 100-200\% higher than those from China (USITC, 2009: I-20), and yet no global safeguard by the United States was attempted. Had the USW filed a petition for a global safeguard under Section 201, it might have been turned down because the petitioner would have had difficulty showing sharply increased imports, ${ }^{9}$ serious rather than material injury, and causation under the higher 'substantial cause' standard. As the Appellate Body explained, 'serious injury' is a 'much higher standard' (WTO, 2011a: para. 183).

The question of whether the Protocol was meant to make it easier or harder for WTO Members to impose a temporary safeguard on China should have been answerable by recourse to the fairly recent negotiating history. Oddly, neither party sought to introduce such history. Rather, the Panel decided the key issues through recourse to seven different dictionaries. In doing so, the Panel made no effort to explain how it chose which dictionary it would rely upon for each interpretive exercise.

In our view, China was justified in criticizing the Appellate Body at the DSB meeting. ${ }^{10}$ While agreeing that the cause had to demonstrate an 'important contribution' (WTO, 2011a: paras. 185, 195), the Appellate Body explained that merely being one of several contributing causes was sufficient to meet the TPSSM's causation test (WTO, 2011a: para. 318). The Appellate Body justified this position by holding that because Paragraph 16.1 of the Protocol did not use the term 'significant', it would interpret Paragraph 16.4 'harmoniously' to infer less meaning to the term 'significant' in Paragraph 16.4 (WTO, 2011a: para. 182). This was an error by the Appellate Body. Paragraph 16.1 of the Protocol refers to consultations, rather than to the right of action. Paragraph 16.4 of the Protocol clearly requires a 'significant cause' standard, and it was inappropriate for the Appellate Body to characterize Paragraph 16.1 as diluting Paragraph 16.4.

The data show that the China safeguard may have succeeded in lowering tire imports from China to the United States from 45.6 million in 2009 to 29.7 million

9 The Appellate Body has suggested that the increase in imports has to be recent, sudden, and sharp, and in the Tyres case total imports rose from 113 million in 2004 to 140 million in 2007 and 139 million in 2008.

10 In addition, the Appellate Body was wrong in arguing that the lower standard for injury in the Protocol was probative in imbuing meaning to the term 'significant cause'. See WTO (2011: paras. 182184). 
in 2011. Yet over the same period, total US tire imports rose from 125 million in 2009 to 150 million in 2011. Such an outcome is not surprising as a partial (country-specific) safeguard is likely to be ineffective in (temporarily) lowering overall imports if there are many competing suppliers. If so, a partial safeguard, such as the TPSSM, is simply an opportunity to discriminate against one country of origin while allowing competing countries to fill the supply gap.

That is what happened in this dispute. As China explained to the DSB:

It was puzzling that the United States expected to rescue its tyre industry out of the economic crisis by imposing punitive duties on China's tyres through the productspecific safeguard measures. Predictably, the measures did not work. They injured China's legitimate trading interests, but did not help reduce the US imports of tyres ... The US measures merely distorted international trade. (WTO, 2011b: para. 8)

Such distortion of international trade is a byproduct of the one-way discrimination allowed in the TPSSM. China is made to bear the full costs of the protection erected by the United States. ${ }^{11}$ The costs to China will far exceed the benefits accruing to the US producers because other foreign suppliers to US markets filled in the gap. As discussed below, the safeguard did lead to trade deflection and a shuffling of import market shares without materially affecting domestic employment in tire production in the United States. The import market outcome from the safeguard turned out to be exactly the opposite of what the USITC predicted.

Of course, China's observation raises the question of what the Obama Administration's intention was in imposing the safeguard. Even if it did not substantially increase domestic production in the US tire industry, the safeguard may have succeeded in the political purpose of gratifying the rubber-workers union (Will, 2009) and/or of appearing to be punishing China without generating significant costs to US households (insofar as replacing China with other sources of low-cost tires meant that a selective safeguard would only have a moderate effect on retail prices). In the last several weeks of the US Presidential campaign, the China tires case became another bone of contention between the two candidates (Hohmann, 2012).

\subsection{WTO Law of Safeguards}

To date, the WTO case law has not been kind to countries using global safeguards; every case that has been contested has been lost by the safeguard-invoking country. ${ }^{12}$ In part, this is because key terms such as 'unforeseen developments',

11 If China were able to find third-country markets for those tires, then it could reduce some of those costs. Nevertheless, such exports to third countries could further distort international trade.

12 Of course, most safeguards are not contested in the WTO. A snapshot of WTO data shows 33 global safeguards in effect on 26 October 2011 of which only one has been contested so far. See G/L/972, 1 November 2011. 
'serious injury', 'increased quantities', and 'cause' are not defined in the Safeguards Agreement. Without clarity regarding the baseline to be applied to imports, how to assess the link between imports and injury, and what constitutes an 'unforeseeable' event that generates an import surge, governments confront great uncertainty on whether the approaches they follow in determining whether to impose safeguards will pass muster by a WTO Panel and the Appellate Body.

Sykes (2003, 2004) and Grossman and Sykes (2007) have argued that the Appellate Body has made it very difficult for countries to apply safeguards by utilizing the language in Article XIX GATT in reviewing challenged safeguards without clarifying the meaning of the key terms. Particularly problematic has been the insistence on applying the 'unforeseen developments' test to safeguard actions. In practice, this test had ceased to be applied or considered relevant by GATT contracting parties, and for that reason presumably was not included in the Agreement on Safeguards. The re-introduction of this test by the Appellate Body appeared to reverse the intent of those who had negotiated the Safeguards Agreement. Overall, 'Appellate Body decisions since the inception of the WTO have only made matters worse, to the point that the legal requirements for the use of safeguards are largely incoherent, and no nation can employ them without the near certainty of defeat in the dispute resolution process should they be challenged' (Grossman and Sykes, 2007: 91). Sykes (2003) concludes that the incoherence can only be resolved through a re-negotiation of the agreement or through action by the Appellate Body to define key terms.

In negotiating China's Protocol of Accession, WTO Members were apparently unwilling to rely on the global safeguards available under the Agreement on Safeguards. This unwillingness must have reflected a view that the available global safeguards were inadequate. So the TPSSM can be understood as a temporary patch for the WTO's dysfunctional safeguard program. As noted above, the patch dissolves after 2013 when safeguards against China must conform to regular WTO law.

The inadequacy of the WTO global safeguard arose from two problems in WTO dispute settlement. One was that the Appellate Body inserted a requirement to demonstrate 'unforeseen developments' that had not been included in Article 2.1 of the Safeguards Agreement. The other was that WTO adjudicators gave limited deference to the safeguard decisions of domestic authorities. ${ }^{13}$

Neither of these problems occurred in the US-Tyres case. As discussed above, the Panel did not require the USITC to demonstrate unforeseen developments, and the

13 For example, see Panel Report, Dominican Republic-Safeguard Measures on Imports of Polypropylene Bags and Tubular Fabric, WT/DS415, 416, 417, 418/R, adopted 22 February 2012, paras. 7.314-7.315; Appellate Body Report, Argentina-Safeguard Measures on Imports of Footwear, WT/DS121/AB/R, adopted 12 January 2000, paras. 129-131; Appellate Body Report, United States-Definitive Safeguard Measures on Imports of Circular Welded Carbon Quality Line Pipe from Korea, WT/DS202/AB/R, adopted 8 March 2002, paras. 218-222. 
Panel was very deferential to the USITC on both facts and the application of Accession law. For example, the Panel properly ruled that it was not its role to decide whether the USITC majority or minority were correct. It is probably a vain hope that a deferential stance will be channeled back into regular safeguard cases. In the only safeguard dispute since Tyres, Dominican Republic-Bags, the Panel did cite the US-Tyres case, but did not show any of the deference of the Tyres Panel.

\subsection{WTO Law of Accession}

An accession protocol is formally an agreement between the WTO and the applicant country, and such protocols are not listed among the covered agreements subject to adjudication under the DSU. ${ }^{14}$ So far, no theory of enforceability of accession agreements has emerged in WTO dispute settlement. The Panels and Appellate Body have enforced the agreements in all of the accession cases, but have not explained why, and parties have not questioned such enforceability. In US-Tyres, China did not challenge enforceability. The Appellate Body pointed out that the Protocol itself provides that it 'shall be an integral part' of the WTO Agreement (WTO, 2011a: para. 118), but that does not help in explaining enforceability because one would presume that international agreements cannot contract themselves into the WTO merely by self-certifying that they are integral parts of the WTO Agreement. The WTO has provisions for amendments in Article $\mathrm{X}$, but those provisions were not used for the China accession. It may be that an accession agreement has the capacity to implicitly amend the WTO (see Charnovitz, 2008: 893), but even this solution is problematic because there is no obvious constitutional limiting principle for what can be put into the WTO through an accession agreement.

In contrast to the two previous WTO accession cases, the Tyres panel and Appellate Body did not tiptoe around some of the knotty doctrinal issues of the law of accession. Indeed, the Panel held that the China Protocol was a 'covered agreement' and the Appellate Body held that it was a 'WTO agreement'. ${ }^{15}$ The Panel showed no hesitation in considering the Protocol as a 'covered agreement' for the purpose of using as the interpretive framework the Vienna Convention on the Law of Treaties (WTO, 2010: paras. 7.23, 7.32, 7.149) even though the Vienna Convention does not apply to treaties between states and international organizations.

Besides enforceability, the other key doctrinal challenge in accession is how the rules of the accession agreement relate to the multilateral rules in WTO agreements (Charnovitz, 2008: 905-911). For example, does GATT Article I trump an accession agreement or does the accession agreement trump GATT Article I?

14 See WTO Agreement, Art. XII:1 and DSU Appendix 1.

15 WTO (2010, paras. 7.15, 7.24). WTO (2011, paras. 120, 121, 181, 201). It is interesting to note that the WTO Secretariat now includes accession agreements as 'agreements' in the list of WTO covered agreements. See http://www.wto.org/english/tratop_e/dispu_e/find_dispu_cases_e.htm\#results (last visited 1 November 2012). 
The relationship of accession law to general WTO law had arisen in the two previous accession cases, but only through the interpretation of terms in the accession agreement. In the Tyres case, by contrast, the Panel ruled that the US safeguard did not violate GATT Article I without relying on specific language in the accession agreement. Yet it is hard to know what to make of this precedent because the Panel, unaccountably, did not offer any transparent reasoning to justify its decision.

Although the TPSSM is ostensibly separate from the WTO Agreement, ${ }^{16}$ both the Panel and the Appellate Body borrowed copiously from WTO jurisprudence to interpret the TPSSM. Such borrowing occurred in the two previous accession cases and showed a volition by Panels to interpret accession rules in an integrative fashion with general WTO law. Indeed, the Panel cited 23 WTO cases, only five of which were safeguard cases and none of which was previous accession cases. The Appellate Body was even more mimetic in citing 22 additional WTO cases. That WTO adjudicators interpreting the TPSSM would draw upon existing traderemedy case law was predicted well in advance by thoughtful trade-law analysts (see Andersen and Lau, 2002).

\section{Economic observations}

\subsection{Material injury}

The TPSSM uses the terms 'domestic producers' and 'domestic industry' but does not define them. Yet the focus of the USITC determination whether the tire industry was materially injured was on productive activity in the United States. It is not clear to us that this is the proper interpretation. Whether there was material injury of the domestic US industry was contested by respondents before the USITC but not by China at the WTO.

The US tire industry is a global industry, dominated by large multinationals. These firms make production-location decisions on the basis of expected demand in the major markets they serve, and balance off differences in production costs across locations against the trade and other transactions costs that are associated with serving a market through exports. While employment, capacity, and output in the United States may fall, the financial returns of the major tire companies were healthy until the global recession struck. Weak economic activity in one market - the United States - need not signal the industry is 'injured'.

\subsection{Causation and definition of like products (relevant market)}

In bringing the case, the USW argued that the decline in US production of tires was due to import competition. US tire producers argued that the decline reflected a decision to exit the tier-3 segment as other varieties and products were more 
profitable, and that this was a major reason why imports were not a cause of material injury. Instead, the observed injury reflected the business cycle and other demand factors.

It is difficult empirically to separate these two claims, as deliberately exiting a segment for which there is demand will by definition result in increased imports. One can get a sense of the relationship by determining if Chinese imports began to rise (faster) after US plants producing tier-3 tires were closed. This was not done in the investigation - indeed there is little explicit focus on what the plants that were shut down in the 2004-2008 period were producing, and where and in what type of production tire producers were investing inside and outside the United States.

Two USITC commissioners had a dissenting view on whether imports from China met the required injury-causation standard. This became a key argument for China in the dispute - the question being how imports from China could be a significant cause of material injury when $80 \%$ of US production in 2008 was of tier-1 and tier-2 tires, while most Chinese imports were in tier 3. China also raised this question on appeal. The dissenting Commissioners found that imports were not a significant cause of material injury, but rather that the US industry had consciously and deliberately been pursuing a gradual exit from producing low-margin tires.

No effort was made in the USITC report to assess quantitatively the degree of substitutability of Chinese for US tires in general-beyond a qualitative questionnaire-and not at all for substitution across tiers. The Panel and the Appellate Body simply noted their agreement with the USITC in concluding that tires are technically good substitutes - any tire of the right size for any given rim will 'work' and all tires must satisfy specific safety standards, so in that sense 'a tire is a tire is a tire', whether it is tier 1,2 , or 3.

This is questionable from an economic perspective. Tires are differentiated products that vary in quality, with significant investments made by producers in brands and marketing that presumably have a positive rate of return. To argue that such differentiation is not relevant from the perspective of assessing whether imports have a negative effect seems inappropriate.

The question then is whether a more narrow definition of the relevant market would have made a difference. China exports primarily one variety of tiresnamely, unbranded, low-end products. If one takes the view that the investigation should have been limited to this segment of the market, it would have been much more likely that the 'correctly defined' domestic industry that produces such tires would have been found to be materially injured, addressing the concerns expressed by the dissenting Commissioners. ${ }^{17}$ Conversely, if one sticks with a focus on the tire

17 In the USITC questionnaire, 7 out of 10 US producers stated they had not suffered negative effects from Chinese imports; one indicated its credit rating and capital investment had declined; and only two noted reductions in production. As no information is provided that allows the firms to be identified, it is not 
industry as a whole but takes a narrow view of defining like products, it would clearly be much harder to claim that the material injury that is observed across the broader industry (i.e., all three tiers) is due to imports from China. All we would point out here is that the analysis offered by the USITC is not very rigorous, making no effort for example to estimate the relevant substitution elasticities. Conversely, the Panel and Appellate Body make much of the fact that the respondents in the USITC case could not agree on what differentiated tier 3 from tiers 1 and 2 .

\subsection{Trade deflection}

According to USITC data, the value of total imports of tires in 2008 was $\$ 7.9$ billion, of which China accounted for $\$ 2$ billion (see Table 1). In 2009, as a result of the recession caused by the financial crisis, total imports fell to $\$ 6.9$ billion $(-13 \%)$, with Chinese exports dropping by a similar proportion (11.6\%). In 2010, the first full year of the special safeguard, the value of imports from China fell by another $12.4 \%$, as compared to growth in the overall value of tire imports, which expanded by almost $29 \%$ to $\$ 8.9$ billion. Virtually all sources of import supply saw growth. Canada became the biggest foreign supplier of tires by value in 2010 ( $\$ 1.8$ billion) as a result of a $20 \%$ rise in export value between 2009 and 2010. Countries that saw the largest growth in percentage terms included Japan $(40 \%)$, Korea $(83 \%)$, Thailand (81\%), Mexico (42\%), Indonesia (77\%), and Taiwan $(134 \%)$. Canada and Japan, the number 1 and 3 import sources by trade value, tend to produce high-quality, branded, tier-1 tires. Thus, it appears that the decline in Chinese exports was offset by imports from other countries in East Asia. ${ }^{18}$

A similar pattern is observed if one focuses on developments in the value and destination of China's tire exports. The value of China's reported exports to the United States fell by $8 \%$ in 2009 and by another 19\% in 2010, and the Chinese share of the US market fell from 39\% in 2009 to $19 \%$ in 2011. But China's exports to 'the rest of the world' increased $74 \%$ between 2009 and 2011, rising from $\$ 3.2$ billion to $\$ 5.6$ billion. 19

The total value of US imports of tires increased 54\% between 2009 and 2011 (Table 1). Thus, the safeguard had a large effect on Chinese exports to the United States, but much of the affected tires appear to have been redirected to other markets, with other exporters taking up the slack-i.e., the main effect was to 'shuffle' sources of supply and export market destinations. Such shuffling can also be inferred from developments in the volume of imports from different sources.

possible to determine what share of the industry the adversely affected firms have. But the response by the 'most vocal' respondent (longest reply) to the question of anticipated effects indicates that firm is small.

18 See Lee (2011) for an empirical analysis. Korea and Thailand rank 8th and 9th in global exports of rubber/plastic products; Taiwan ranks 14th. In Thailand and Indonesia, exports are mostly driven by foreign direct investment.

19 These numbers were obtained from United Nations Commodity Trade, accessed through World Integrated Trade Solution. 
Table 2. US tire imports (quantities, 2007-2011)

\begin{tabular}{|c|c|c|c|c|c|}
\hline \multirow[b]{2}{*}{ Country } & \multicolumn{5}{|c|}{ In 1,000 units of quantity } \\
\hline & 2007 & 2008 & 2009 & 2010 & 2011 \\
\hline China & 46,876 & 49,761 & 45,570 & 34,582 & 29,650 \\
\hline Canada & 22,622 & 20,562 & 18,842 & 22,396 & 22,671 \\
\hline Korea & 15,122 & 14,576 & 11,961 & 21,386 & 22,226 \\
\hline Japan & 19,126 & 17,397 & 14,036 & 19,314 & 16,593 \\
\hline Thailand & 3,637 & 4,927 & 4,781 & 8,512 & 10,805 \\
\hline Indonesia & 5,976 & 5,959 & 5,392 & 9,333 & 10,267 \\
\hline Mexico & 4,892 & 5,350 & 5,058 & 7,435 & 9,827 \\
\hline Taiwan & 4,464 & 3,539 & 2,277 & 5,211 & 5,158 \\
\hline Brazil & 6,105 & 5,850 & 4,830 & 5,738 & 4,551 \\
\hline Germany & 4,335 & 3,253 & 2,192 & 2,620 & 3,553 \\
\hline Total & 152,990 & 148,461 & 124,978 & 149,597 & 150,256 \\
\hline
\end{tabular}

Source: USITC website.

While China remains the largest foreign supplier of tires to the United States, reflecting the low unit values of the tires that are exported to the United States (Table 2), other countries saw a significant increase in shipments to the United States after the safeguard. The countries that appeared to be competing most directly with China on price were Indonesia and Taiwan. Both had average unit values of around $\$ 35$ in 2009 and 2010. Together these two countries exported an additional 9 million tires in 2010, which was almost equal to the 11-million-unit decline experienced by China. Korea and Mexico, two other countries that saw very large increases in exports to the United States, appeared to be selling somewhat higher-quality tires, with unit values averaging \$54 in 2009 and 2010. Note, however, that the overall decline in China's exports to the United States was 20 million tires and that the low-end producers did not come near to filling that gap-indicating that average prices increased after the safeguard was imposed. ${ }^{20}$ There was an across-the-board increase in unit values in 2011 that was driven in part by rising costs of rubber and oil (Table 3). Unit values for Indonesia and Taiwan increased to the \$42-44 range, but unit values of Chinese exports rose much more proportionately - from $\$ 38$ in 2009 to $\$ 44$ in 2010 to $\$ 61$ in 2011.

20 Hufbauer and Lowry (2012) argue that unit values of tire imports rose in the 4th quarter of 2009 - the period immediately after the imposition of the $35 \%$ tariff - by an amount that translates into an $\$ 800$ million annualized increase in prices paid by US consumers for tires. This may be an over-estimate. Prices certainly increased in 2009 and thereafter, but this appears to be mostly driven by higher input costs and a recovery in demand. There is no mention of the effect of the tariff in industry literature - this seems mostly limited to articles in the popular press (e.g., Bussey, 2012). Account also needs to be taken of the rapid increase in exports from countries at unit values that are similar to those of China before the safeguard. 
Table 3. US tire imports (unit values, 2007-2011)

\begin{tabular}{lccccc}
\hline \hline \multirow{5}{*}{ Country } & \multicolumn{2}{l}{ US dollars/unit of quantity } & & \\
\cline { 2 - 6 } & 2007 & 2008 & 2009 & 2010 & 2011 \\
\hline China & 38.1 & 39.6 & 38.2 & 44.1 & 60.7 \\
Canada & 65.8 & 70.2 & 78.7 & 79.6 & 85.7 \\
Korea & 51.0 & 53.9 & 53.5 & 54.7 & 65.4 \\
Japan & 58.9 & 66.7 & 76.8 & 77.4 & 88.5 \\
Thailand & 74.2 & 67.4 & 62.0 & 63.0 & 74.3 \\
Indonesia & 26.2 & 29.3 & 34.5 & 35.4 & 44.3 \\
Mexico & 52.0 & 55.7 & 54.3 & 52.4 & 57.9 \\
Taiwan & 38.0 & 36.3 & 35.3 & 36.1 & 42.1 \\
Brazil & 45.4 & 51.0 & 51.6 & 57.7 & 74.8 \\
Germany & 59.5 & 74.6 & 81.9 & 87.3 & 98.4 \\
\hline \hline
\end{tabular}

Source: USITC website.

This may reflect some shift towards higher-quality exports as well as the effect of the tariffs.

\subsection{Effectiveness of tariffs as an instrument to address adjustment costs}

The US-Tyres case illuminates a basic flaw in the Safeguards Agreement, which is that its sole instrument, a trade restriction, may have little effectiveness and relevance in helping workers address adjustment problems. In an era of limited economic globalization, there was a greater unity of interest of domestic workers and producers, and so a trade restriction for import-competing producers could reliably help both those producers and their workers. While raising tariffs or other barriers to trade is detrimental to consumers, the interests of the factors of production employed in an import-competing industry were likely to be aligned.

Today, with global supply chains and increasing fragmentation of global production, the situation may be very different. The Tyres case illustrates the point. The issue was noted by the Tyres Panel in pointing out that there was a 'question of the suitability or relevance of safeguard mechanisms in the context of "outsourcing" and "globalization" (WTO, 2010, para. 7.9). A cynical view of the Tyres dispute might say that it provided protection to the domestic industry that it did not want, and minimal relief to the workers who were never going to regain the jobs that had been purposefully outsourced.

The trade deflection that resulted from the discriminatory nature of the China safeguard measure meant that it achieved little in terms of expanding US-produced output and increasing employment in the tire-building industry. Hufbauer and Lowry (2012) argue that the safeguard at most saved 1,200 jobs, based on the observed rise in industry employment between September 2009 and September 2011. This is exactly what the USITC analysis had suggested (USITC, 2009: 37, n.205). 
More realistically, however, the impact on tire-manufacturing jobs was zero. Total employment in the tire industry stood at 52,000 workers in late 2009; in 2011 it was also 52,000. ${ }^{21}$ A narrower occupational definition of tire builders and molders indicates total employment of 16,700 workers in 2011 , down from 17,800 workers in 2009 and 21,700 in 2008, but up from 15,000 in 2010. ${ }^{22}$ This suggests that during 2009-2011 total employment fell. Moreover, any increase in jobs-even if it was 1,200-needs to be assessed in the context of the 5,000 jobs that the USITC found had been lost during the period of investigation (USITC, 2009: 17), and any jobs lost in related service activities as a result of safeguardinduced higher retail prices for tires-garages, retail outlets, etc. (Prusa, 2009; Hufbauer and Lowry, 2012).

Nearly three years after the imposition of the safeguard, the evidence suggests that the economic returns have been meager at best and more likely negative. The employment numbers illustrate the inefficacy of a tariff to save or create jobs in an industry that is organized globally and that allocates production of different varieties of its product mix to countries that have a comparative advantage to produce them. A tariff instrument is unlikely to be useful in safeguarding a country's competitiveness in a world of vertical specialization and global production. A targeted tariff may provide benefits to a discrete set of workers (see USW, 2012), but it will do so only if a country has an industry that produces the products at issue. If production has largely been shifted to locations in other countries, the efficacy of trade-policy remedies is inherently limited and the cost-benefit ratio of increasing import tariffs for the nation as a whole increases. In the limit, if there is no local production, the only effect of raising tariffs is to tax consumers and workers generally.

These weaknesses may have implications for the operation of the trading system looking forward. One possible consequence of the ineffectiveness of selective protection may be a push towards relaxing the requirements for global safeguards so as to make it easier to raise tariffs on all imports so as to induce greater domestic production. This would clearly be very costly from an economic-efficiency and consumer-welfare perspectives.

What is needed is a greater effort to identify and make available alternative instruments to assist workers who are negatively affected by globalization. Instead of centering the Safeguards Agreement on raising the price of imports, the Agreement should be restructured as a positive mechanism to promote greater competitiveness and job creation in WTO Member countries (Charnovitz, 2006: 140-146). The Safeguards Agreement recognizes the goal of 'facilitating

21 As reported in the Bureau of Labor Statistics (BLS) Current Employment Statistics database for NAICS sector 3236210, which spans all tire production, including heavy trucks and retreading. This is down from 59,000 in 2007-2008. See http://www.bls.gov/ces/ (last visited 1 November 2012).

22 These figures are for Standard Occupational Classification sector 519197 as reported in the BLS Occupational Employment Statistics. See http://www.bls.gov/oes/ (last visited 1 November 2012). 
adjustment' (see Article 7.4), but does not contain instruments suitable for that purpose (Horn and Mavroidis, 2003: 405). ${ }^{23}$

\subsection{Other issues}

This case raises a number of political-economy questions and puzzles, some of which have already been mentioned. For example, did the union truly believe that raising import protection would save US jobs in the tire industry or were there other considerations that motivated the case? The likelihood that the measure would only generate trade deflection was clearly identified by analysts at the time (Prusa, 2009). It may be that this was not believed. The USITC analysis that the recommended tariff would expand US production and employment may have played a role here.

Another question is why did the majority of the industry oppose the case given that they were exiting or had already abandoned the tier-3 segment? If the case led to higher prices for low-end tires, this would presumably induce some consumers to upgrade their tires. If it led to deflection, it presumably would not have much of an effect. One factor underpinning the opposition might have been a fear of disruption to the operation of affiliates in China. Of total tire imports of 139 million tires in 2008, 75 million units originated in US-owned plants or joint ventures. While only a little over $10 \%$ of this quantity ( 8 million units) originated in China, it accounted for some $20 \%$ of total imports of tires from China. Another factor might have been a concern with possible retaliation by China. The Chinese government did retaliate against a nonautomotive-related sector (chicken parts), using an antidumping measure - see Bradsher (2009). ${ }^{24}$

As noted, US imports of tires in 2008 from most other countries had higher unit values than those from China. This suggests some firms could benefit from restrictions on Chinese imports if a significant share of the expected increase in imports from non-Chinese sources would involve plants in which US firms have a stake-especially if the safeguard led to a significant increase in prices (as the difference between the unit costs of Chinese and non-Chinese tires would be reduced). All non-Chinese imports taken together from other developing countries in 2008 (some 25 million units) were less than total imports from China (46 million), suggesting that a significant trade restriction along the lines of what the USW was looking for (a limit of 21 million units) could have had such effects.

23 Of course, there is no constraint imposed on WTO members to put in place domestic mechanisms to assist workers-as the United States has done. An important policy question is whether the recommendations by the USITC to expedite petitions for trade-adjustment assistance by tire-industry workers were implemented, and to determine what could be done to enhance the effectiveness of such assistance.

24 Under the accession protocol, if a safeguard measure is taken as a result of a relative (absolute) increase in the level of imports, China has the right to suspend the application of substantially equivalent concessions or obligations if the measure remains in effect more than two (three) years (WTO, 2001: para. $16: 6)$. 


\section{Conclusion}

The US-Tyres case provides a vivid illustration of an incumbent WTO-Minus accession law in operation. China's Accession Protocol made it easier for other WTO Members to impose a safeguard against China than would have been the case if the regular WTO rules in the Safeguards Agreement had to be used. Moreover, WTO Members were permitted to target the safeguard solely against China, something that is not possible under the Safeguards Agreement.

This was an unusual case in that it was brought by the steelworkers labor union rather than by the industry - which did not think import barriers were justified or useful to it. In our view, the Appellate Body and Panel exhibited a proper level of deference to the decision issued by the competent national authorities (namely, the USITC and the US President). We hope that future Panels in safeguard cases seek to show the same level of deference.

As the only WTO dispute to date to bless the use of a safeguard, the Tyres case may suggest either that WTO safeguard law is being interpreted too stringently or that WTO safeguard law needs to be liberalized. Presumably, the labor union that brought the case would have petitioned for a global safeguard if they thought the relevant conditions had been satisfied. The fact that there was no such petition suggests that the TPSSM was seen to provide a path to import relief that would not have otherwise been available in the absence of the special rules in China's accession contract. Rather than relax the criteria for obtaining global safeguards protection, we believe the case illustrates the importance of reconceiving the Safeguards Agreement with more efficient (less costly) and more effective instruments to promote economic adjustment for workers and communities.

Finally, the Tyres case is notable in its holding that an accession commitment is a covered agreement to be interpreted in the same manner as regular WTO law, and the Panel ruling that the TPSSM does not violate GATT Article I, even though the safeguard is applied only to China. The Panel did not explain the basis for this ruling despite the duty of a WTO judge to do so.

\section{References}

Andersen, Scott and Christian Lau (2002), 'Hedging Hopes with Fears in China's Accession to the World Trade Organization: The Transitional Special-Product Safeguard for Chinese Exports', The Journal of World Intellectual Property, 5(3): 405-476.

Bank of America/Merrill Lynch (2010), 'Global Tire Quarterly Review', July.

Bown, Chad P. (2011), 'Taking Stock of Antidumping, Safeguards and Countervailing Duties, 1990-2009', The World Economy, 34(12): 1955-1998.

Bradsher, Keith (2009), 'China Moves to Retaliate against US Tire Tariff', The New York Times, 13 September.

Bussey, John (2012), 'Get-Tough Policy on Chinese Tires Falls Flat', The Wall Street Journal, 20 January, available at http://online.wsj.com/article/SB10001424052970204301404577171130489514146.html (last visited 2 November 2012). 
Charnovitz, Steve (2006), 'The (Neglected) Employment Dimension of the World Trade Organization', in Virginia A. Leary and Daniel Warner (eds.), Social Issues, Globalisation and International Institutions: Labour Rights and the EU, ILO, OECD and WTO, Leiden, The Netherlands: Martinus Nijhoff Publishers, pp. 125-155.

Charnovitz, Steve (2008), 'Mapping the Law of WTO Accession', in Merit E. Janow, Victoria Donaldson, and Alan Yanovich (eds.), The WTO: Governance, Dispute Settlement and Developing Countries, Huntington, NY: Juris Publishing, pp. 855-920.

Eisenstein, Adam (2010-2011), 'Free Trade, Tires, and Tariffs: Why Imposing Import Duties Against Chinese Goods is the Wrong Course of Action for the United States', The Federal Circuit Bar Journal, 20(2): 305-335.

Grimmett, Jeanne J. (2011), 'Chinese Tire Imports: Section 421 Safeguards and the World Trade Organization (WTO)', CRS Report R40844, July.

Grossman, Gene M. and Alan O. Sykes (2007), 'United States - Definitive Safeguard Measures on Imports of Certain Steel Products', World Trade Review, 6(1): 89-122.

Hohmann, George (2012), 'Cheap Chinese Tires Become Election Issue', Charleston Daily Mail (West Virginia), 29 October.

Horn, Henrik and Petros C. Mavroidis (2003), 'US - Lamb United States - Safeguard Measures on Imports of Fresh, Chilled or Frozen Lamb Meat from New Zealand and Australia: What Should Be Required of a Safeguard Investigation?' World Trade Review, 2(3): 395-430.

Hufbauer, Gary Clyde and Sean Lowry (2012), 'US Tire Tariffs: Saving Few Jobs at High Cost', Policy Brief 12-9 (April), Petersen Institute for International Economics, available at http://www.iie.com/ publications/pb/pb12-9.pdf (last visited 2 November 2012).

Ikenson, Daniel (2009), 'Burning Rubber: Proposed Duties on Chinese Tires Whiff of Senseless Protectionism', Free Trade Bulletin 39, Center for Trade Policy Studies, available at http:// www.cato.org/pubs/ftb/FTB-039.pdf (last visited 2 November 2012).

Ji, Wenhua and Cui Huang (2011), 'China's Experience in Dealing with WTO Dispute Settlement: A Chinese Perspective', Journal of World Trade, 45(1): 1-37.

Lee, Joonhyung (2011), 'Who Benefited from the US Tariffs on the Chinese tires?', MPRA Paper No. 29705, available at http://mpra.ub.uni-muenchen.de/29705/1/MPRA_paper_29705.pdf (last visited 2 November 2012).

Lee, Yong-Shik (2002), 'The Specific Safeguard Mechanism in the Protocol on China's Accession to the WTO: A Serious Step Backward from the Achievement of the Uruguay Round', The Journal of World Intellectual Property, 5(2): 219-231.

Obama, Barack H. (2012), 'Remarks by the President in State of the Union Address', White House, 24 January.

Prusa, Thomas J. (2009), 'Estimated Economic Effects of the Proposed Import Tariff on Passenger Vehicle and Light Truck Tires from China', American Coalition for Free Trade in Tires, July.

Rajan, Raghuram G., Paolo Volpin, and Luigi Zingales (1997), 'The Eclipse of the US Tire Industry', Working Paper No. 97-13, US Census Bureau, Center for Economic Studies.

Spadi, Fabio (2002), 'Discriminatory Safeguards in the Light of the Admission of the People's Republic of China to the World Trade Organization', Journal of International Economic Law, 5(2): 421-443.

Sykes, Alan O. (2003), 'The Safeguards Mess: A Critique of WTO Jurisprudence', World Trade Review, 2(3): 261-295.

Sykes, Alan O. (2004), 'The Persistent Puzzle of Safeguards: Lessons from the Steel Dispute', John M. Olin Law and Economics Working Paper No. 212 (2nd Series), The University of Chicago Law School, available at http://www.law.uchicago.edu/files/files/212.aos_.steel_safeguards.pdf (last visited 2 November 2012).

Tire Industry Association (2009), 'Tire Industry Association Expresses Disappointment With President's Decision Concerning Chinese Tire Tariff', Press release, 14 September, available at http:/l www.tireindustry.org/pdf/news_archives/pressrelease091409.pdf (last visited 2 November 2012).

US International Trade Commission (USITC) (2009), Certain Passenger Vehicle and Light Truck Tires from China, Washington DC: USITC (July), available at http://www.usitc.gov/publications/ safeguards/pub4085.pdf (last visited 2 November 2012). 
United Steelworkers (USW) (2012), 'Saving Jobs by Fighting Unfair Trade', available at http:// www.usw.org/media_center/news_articles?id=1079 (last visited 2 November 2012).

Will, George (2009), 'With China Tire Tariffs, Obama Bows to Labor', The Seattle Times, 24 September.

World Trade Organisation (WTO) (2001), 'Accession of the People's Republic of China', WT/L/432, 23 November.

World Trade Organisation (WTO) (2010), United States-Measures Affecting Imports of Certain Passenger Vehicle and Light Truck Tyres from China, Panel Report, WT/DS399/R.

World Trade Organisation (WTO) (2011a), United States-Measures Affecting Imports of Certain Passenger Vehicle and Light Truck Tyres from China, Appellate Body Report, WT/DS399/AB/R.

World Trade Organisation (WTO) (2011b), 'Minutes of Meeting Held on 5 October 2011', Dispute Settlement Body, WT/DSB/M/304.

\section{Appendix: WTO China-Specific Safeguard (excerpts)}

16. Transitional Product-Specific Safeguard Mechanism

1. In cases where products of Chinese origin are being imported into the territory of any WTO Member in such increased quantities or under such conditions as to cause or threaten to cause market disruption to the domestic producers of like or directly competitive products, the WTO Member so affected may request consultations with China with a view to seeking a mutually satisfactory solution, including whether the affected WTO Member should pursue application of a measure under the Agreement on Safeguards. Any such request shall be notified immediately to the Committee on Safeguards.

3. If consultations do not lead to an agreement between China and the WTO Member concerned within 60 days of the receipt of a request for consultations, the WTO Member affected shall be free, in respect of such products, to withdraw concessions or otherwise to limit imports only to the extent necessary to prevent or remedy such market disruption. Any such action shall be notified immediately to the Committee on Safeguards.

4. Market disruption shall exist whenever imports of an article, like or directly competitive with an article produced by the domestic industry, are increasing rapidly, either absolutely or relatively, so as to be a significant cause of material injury, or threat of material injury to the domestic industry. In determining if market disruption exists, the affected WTO Member shall consider objective factors, including the volume of imports, the effect of imports on prices for like or directly competitive articles, and the effect of such imports on the domestic industry producing like or directly competitive products. 